Article

\title{
Diversity of Bacteria in Lakes with Different Chlorophyll Content and Investigation of Their Respiratory Activity through a Long-Term Microcosm Experiment
}

\author{
Hera Karayanni *(D), Sofia C. Macingo, Vasilis Tolis and Dimitrios Alivertis \\ Department of Biological Applications and Technology, University of Ioannina, 45110 Ioannina, Greece; \\ ertiona@hotmail.com (S.C.M.); tolisva2@yahoo.gr (V.T.); dimitris.alivertis@gmail.com (D.A.) \\ * Correspondence: hkaray@cc.uoi.gr
}

Received: 10 January 2019; Accepted: 27 February 2019; Published: 5 March 2019

\begin{abstract}
Bacterial community structure and metabolism are critical factors for ecosystem functioning since they affect remineralization of nutrients and carbon flow. We used Illumina sequencing of 16SrRNA V3-V4 regions to investigate whether bacterial assemblage composition differs between four samples from two lakes in the geographic region of Epirus (Greece) characterized by distinct oligotrophic to eutrophic/hypereutrophic conditions as revealed by chlorophyll-a values. We found high similarity $(>60 \%)$ for bacterial assemblages recovered from the two lakes when eutrophic/hypereutrophic conditions prevailed. Distinct bacterial communities appeared in oligotrophic and mesotrophic waters. Low temperature was occasionally an important factor in shaping the bacterial community. In parallel, microcosm experiments were performed to estimate respiration rates of bacterioplankton at in situ temperature and under a $2{ }^{\circ} \mathrm{C}$ temperature increase scenario. Differently assembled communities were found to display similar rates except under hypereutrophic conditions when respiration increased significantly, leading to hypoxic conditions. Temperature increase did not affect respiration rates. Overall this study indicated a clear differentiation of bacterial communities between sites of different trophic state. However, different communities responded similarly under a specific range of chlorophyll-a values and resisted small scale temperature perturbations. Different results were found for hypereutrophic conditions and this has implications for ecosystems functioning, given the increasing occurrence of eutrophication events.
\end{abstract}

Keywords: bacteria; diversity; respiration; lakes; temperature; trophic status; chlorophyll

\section{Introduction}

Bacteria play crucial roles in aquatic ecosystems as decomposers of organic matter, recyclers of nutrients, producers and consumers of greenhouse gases and intermediaries for the flow of energy and matter in food webs [1]. Quantification of bacterial cells is fundamental for aquatic microbiology [2], but it's not enough on its own for a thorough understanding of their contribution to ecosystem functioning, since bacterial abundance may have little, if any, correlation with bacterial activity [3-5]. Thus, in recent years, much effort has been devoted to explore bacterial diversity, so that scientists may answer unresolved questions and better understand previous findings.

Chlorophyll-a is a parameter widely used to describe ecosystems and their trophic state since it is linked to the availability of nutrients and organic substrates and to the onset and decline of phytoplankton blooms [6-8]. Several studies have shown positive correlations between bacterial abundance and chlorophyll-a [9]. Negative correlations have been interpreted as an indication of the dependence of bacteria on allochthonous organic matter [10]. Similarly, bacterial succession 
in lakes may differ depending on whether the dominant available substrate is of phytoplankton or non-phytoplankton origin [11]. Changes in the composition of bacterial communities occur also depending on the phase of phytoplankton blooms and the dominant genera or species, affecting in turn dissolved organic carbon quantity and quality [12-14]. Although other parameters like environmental conditions [15] and top-down factors such as protistan grazing and viral lysis [11,16] may also have an impact on the structure of bacterial communities, distinct assemblages could be expected depending on the trophic status of the ecosystem as revealed by chlorophyll-a content. Indeed, a study in several lakes, rivers and reservoirs in Portugal indicated higher similarities for oligotrophic and mesotrophic water bodies compared to eutrophic/hypereutrophic [17]. However, a different pattern was revealed in reservoirs in Belgium where mesotrophic and eutrophic water bodies exhibited more similarities in respect to an oligotrophic reservoir [18]. A core bacterioplankton community was found across an oligotrophic to urban-eutrophic gradient in Lake Michigan [19]. Nevertheless, distinct bacterial assemblages were revealed in the two habitats and the authors suggested that oligotrophic conditions represented a strong selective force for specific, otherwise cosmopolitan, genera/lineages. This study also highlighted the role the watershed may have in shaping bacterial communities although recent findings from the Great Lakes region showed distinct assemblages for different aquatic habitats (creeks, a river, canals, stormwater outfalls and freshwater lakes) in the same watershed [20]. Trophic state affects not only the composition of bacterial communities but also their richness and evenness (i.e., diversity) since in eutrophic environments, habitat heterogeneity increases, favoring the co-occurrence of multiple taxa [21].

In this study, seasonal patterns of bacterial community composition were investigated in two lakes disturbed by human activities at different degrees. Ziros is a deep, dimictic, mesotrophic lake which is exposed to diffuse agricultural pollution [22] while Pamvotis is a shallow, polymictic, eutrophic/hypereutrophic lake impacted by point and non-point pollution related to the extended urbanization and intense agricultural activity in its catchment area [23]. Bacterioplankton diversity has been investigated in a limited number of freshwater ecosystems in the broader geographic area i.e., north-western Greece, e.g., [24-26], and to our knowledge, this is the first attempt to reveal the diversity of bacterioplankton communities in Greek lakes using high throughput sequencing. We hypothesize that bacterial community composition will converge in lakes/samplings with similar chlorophyll-a content and that taxa richness and diversity will increase in the more eutrophic waters. In parallel, we conducted a microcosm experiment [27] to estimate and compare the respiratory activity (i.e., oxygen consumption) of bacterial assemblages during long-term incubations. In this experiment we investigated also the effect of a temperature increase on bacterioplankton respiration, taking into account that global warming will increase surface water temperature of lakes. We tested a $2{ }^{\circ} \mathrm{C}$ increase since it has been estimated that in a scenario with a $5^{\circ} \mathrm{C}$ air temperature increase there would be a $\sim 3{ }^{\circ} \mathrm{C}$ rise in water temperature, for the most threatened, high latitude ecosystems [28]. This study thus contributes to the continuing effort to characterize freshwater lake bacterioplankton communities around the globe and tries to associate the structure of the communities with their metabolic performance.

\section{Materials and Methods}

\subsection{Sampling - In Situ Abiotic and Biotic Parameters}

Sampling was performed during the warm and the cold period of the year (summer 2016 and winter 2017) in the Ziros and Pamvotis lakes (Region of Epirus, NW Greece). Surface $(0-20 \mathrm{~cm})$ water was collected from one coastal site in each lake into $5 \mathrm{~L}$ well rinsed $(10 \% \mathrm{HCl}$ and milliQ water) polyethylene containers after filtration through a $180 \mu \mathrm{m}$ plankton net. Samples were transferred to the laboratory at $4{ }^{\circ} \mathrm{C}$ in the dark for further processing. Physiochemical parameters (temperature, salinity, total dissolved solids and conductivity) were measured in situ with a Hach sension + EC5 conductivity meter and $\mathrm{pH}$ was determined using $\mathrm{pH}$ paper. Nitrates were determined by ion chromatography 
in Shimadzu HPLC apparatus (detector Shimadzu CDD-10A VP, column shodex IC NI-424, column guard shodex IC NI-G, column oven Shimadzu CTO-10AC, pump Shimadzu LC-20AD). The samples were filtered through $2 \mu \mathrm{m}$ filter paper and $20 \mu \mathrm{L}$ of each sample were injected in HPLC equipped with a conductivity detector with flow rate $1.5 \mathrm{~mL} \mathrm{~min}^{-1}$ and shipping solvent $8 \mathrm{mM} 4$-Hydroxybenzoic acid $+2.8 \mathrm{mM}$ Bis-Tris $+2 \mathrm{mM}$ Phenylboronic acid $+0.005 \mathrm{mM}$ CyDTA aq. Standard solutions of the above ions at concentrations ranging from 1 to $100 \mathrm{mg} / \mathrm{L}$ in seven levels were analyzed as the external calibration basis for quantification. The concentrations of total nitrogen (T-N), $\mathrm{NH}_{4}{ }^{+}, \mathrm{PO}_{4}{ }^{3-}$ and total phosphorus (T-P) of the samples were measured in a HACH DR/2010 Spectrophotometer. T-N and $\mathrm{NH}_{4}{ }^{+}$in the water were determined spectrophotometrically by Total Kjeldahl (Nessler method) $\mathrm{HACH}$ method 8075 at the wavelength of $460 \mathrm{~nm}$. T-P and $\mathrm{PO}_{4}{ }^{3-}$ content were determined by the molybdenum blue method (HACH) after digestion with acid persulfate at $100{ }^{\circ} \mathrm{C}$ for $60 \mathrm{~min}$ when necessary at the wavelength of $880 \mathrm{~nm}$.

Chlorophyll-a (chla) was determined as previously described in detail by Tsola et al. [8]. Water (0.5-2 L) was filtered through $0.7 \mu \mathrm{m}$ (Sartorius, MGF, Goettingen, Germany) and chla was extracted at $4{ }^{\circ} \mathrm{C}$ in $90 \%$ acetone. After centrifugation at $4000 \mathrm{rpm}$, pigment concentration was determined spectrophotometrically using a U2800 Hitachi spectrophotometer. Dissolved oxygen (DO) concentration was measured as described below in 'microcosm experiments'. In situ bacterial abundance was determined by epifluorescence microscopy after fixation with formalin $37 \%(2 \% v / v$ final concentration) and staining with DAPI [29]. At least 10 fields and 300 cells were counted on $0.2 \mu \mathrm{m}$ filters (Isopore membrane filters $25 \mathrm{~mm}$, Millipore, Berlington, MA, USA), using a Leica DM LS2 microscope under UV excitation at magnification X1000.

\subsection{Bacterial Diversity}

Bacterial diversity in each lake and sampling period was investigated through sequencing of the HV regions 3-4 of the $16 S$ gene ( 450bp). DNA extraction was performed with the MoBio PowerSoil Kit (MoBio Inc., Carlsbad, CA, USA) following its standard protocol. The 16S rRNA gene V3-V4 variable region PCR primers S-D-Bact-0341-b-S-17/S-D-Bact-0785-a-A-21 [30] with barcode on the forward primer were used in a 28 cycle PCR using the HotStarTaq Plus Master Mix Kit (Qiagen, Gaithersburg, MD, USA). After amplification, pooled and purified PCR products were used to prepare illumina DNA library. Library preparation and sequencing was performed at MR DNA (Shallowater, TX, USA) on a MiSeq following the manufacturer's guidelines. Sequences were processed using the MOTHUR software v1.30 [31], clustered in Operational Taxonomic Units (OTUs) at 97\% sequence similarity and classified using the SILVA v132 SSU database [32]. Sequences from this study have been submitted to the NCBI Short Read Archive with BioProject ID PRJNA514081. All statistical analyses were done using PAST.3 software.

\subsection{Microcosm Experiments}

For the construction of microcosms, lake water was gently poured using a plastic tube into $\sim 130 \mathrm{~mL}$ amber glass Winkler bottles. In total 6-8 duplicate microcosms were prepared for each lake and each temperature. Microcosms were incubated long-term ( 14 days) [27], at in situ temperature, which ranged between 3.8 and $27.9^{\circ} \mathrm{C}$ during samplings at the two ecosystems, and at temperature increased by $2{ }^{\circ} \mathrm{C}$. Every two days, duplicates from each incubation temperature were 'sacrificed' in order to determine the concentration of dissolved oxygen (DO) by the spectrophotometric Winkler method [33] as described in [8]. The method is suggested for suboxic to supersaturated with DO freshwaters. In brief, adequate volumes of the reagents manganese chloride (3M) and alkaline iodide $(\mathrm{NaOH} 8 \mathrm{M}, \mathrm{NaI} 3 \mathrm{M})$ were added to the samples. Samples were shaken, acidified with sulfuric acid $(10 \mathrm{~N})$ and the absorbance of the resulting from Winkler reactions solution $\left(\mathrm{I}_{2}+\mathrm{I}_{3}{ }^{-}\right)$was measured at $466 \mathrm{~nm}$ using a U2800 Hitachi spectrophotometer. Respiration rates were measured as the slope of changes in $\mathrm{DO}$ concentration (average values of duplicate samples) with time [34]. The $\mathrm{Q}_{10}$ value was calculated to estimate the effect of temperature change on respiration rates. The equation used 
was $\mathrm{Q} 10=(\mathrm{R} 2 / \mathrm{R} 1)^{\wedge}(10 /(\mathrm{T} 2-\mathrm{T} 1))$ where $\mathrm{R} 2$ and $\mathrm{R} 1$ are respiration rates at temperatures $\mathrm{T} 2$ (in situ temperature $+2{ }^{\circ} \mathrm{C}$ ) and T1 (in situ temperature) respectively [34]. We should mention here that experimental bottles contained the whole plankton heterotrophic community $<180 \mu \mathrm{m}$. This was to avoid alterations of bacterial community composition caused by sequential filtrations [35] and in particular in high chlorophyll samples in which filter clogging interrupts flow rate at the initial steps of the filtration [8]. Nevertheless, we considered bacteria as the principal contributors to heterotrophic respiration [36,37] as well as that the encounter rate of bacteria and their predators in the $130 \mathrm{~mL}$ bottles would be low [3]. Finally, we assumed that microalgae abundance decreased due to enclosure e.g., $[38,39]$ and that light limiting conditions did not allow them to recover.

\section{Results}

\subsection{In Situ Abiotic and Biotic Parameters}

During each sampling period, Ziros lake generally gave higher values of the various physicochemical parameters compared to Pamvotis. Temperature minima of $3.8^{\circ} \mathrm{C}$ for Pamvotis and $10.4{ }^{\circ} \mathrm{C}$ for Ziros were found in winter. In summer, the respective temperatures were 21.7 and $27.9^{\circ} \mathrm{C}$. Conductivity in Pamvotis was $288 \pm 6 \mu \mathrm{S} \mathrm{cm}^{-1}$ and total dissolved solids (TDS) $190 \mathrm{mg} / \mathrm{L}$ (not determined in summer). In Ziros lake conductivity was $328 \mu \mathrm{S} \mathrm{cm}^{-1}$ in summer and $399 \mu \mathrm{S} \mathrm{cm}{ }^{-1}$ in winter. The respective values for TDS were 210 and $253 \mathrm{mg} / \mathrm{L}$. Total N (TN) and P (TP) concentration in Pamvotis ranged from 0.08 to $0.9 \mathrm{mg} / \mathrm{L}$ and from 0.7 to $1.2 \mathrm{mg} / \mathrm{L}$ respectively and minima were found in winter. In Ziros in winter TN was $0.3 \mathrm{mg} / \mathrm{L}$ and TP $0.5 \mathrm{mg} / \mathrm{L}$. In summer the respective values were 0.2 and $0.6 \mathrm{mg} / \mathrm{L}$. DO was always higher in Pamvotis and decreased from $10.40 \pm 0.02 \mathrm{mg} / \mathrm{mL}$ in summer to $8.85 \pm 0.13 \mathrm{mg} / \mathrm{mL}$ in winter (Figure 1). On the contrary in Ziros a low increase was found between summer $(5.95 \pm 0.26 \mathrm{mg} / \mathrm{mL})$ and winter $(6.43 \pm 0.00 \mathrm{mg} / \mathrm{mL})$. Chlorophyll-a concentration in Pamvotis was $26.26 \mu \mathrm{g} / \mathrm{L}$ in summer and dropped to $5.63 \mu \mathrm{g} / \mathrm{L}$ in winter. In Ziros lake maximum chla was recorded in winter $(8.69 \mu \mathrm{g} / \mathrm{L}$, Figure 1). Bacterial abundance was similar in the two lakes in summer $\left(12.4 \pm 0.6\right.$ cells $\left.\times 10^{7} \mathrm{~mL}^{-1}\right)$ but followed different trends in winter (Figure 1). In particular in Pamvotis it increased reaching 34.4 cells $\times 10^{7} \mathrm{~mL}^{-1}$ and in Ziros it decreased to 7.73 cells $\times 10^{7} \mathrm{~mL}^{-1}$.

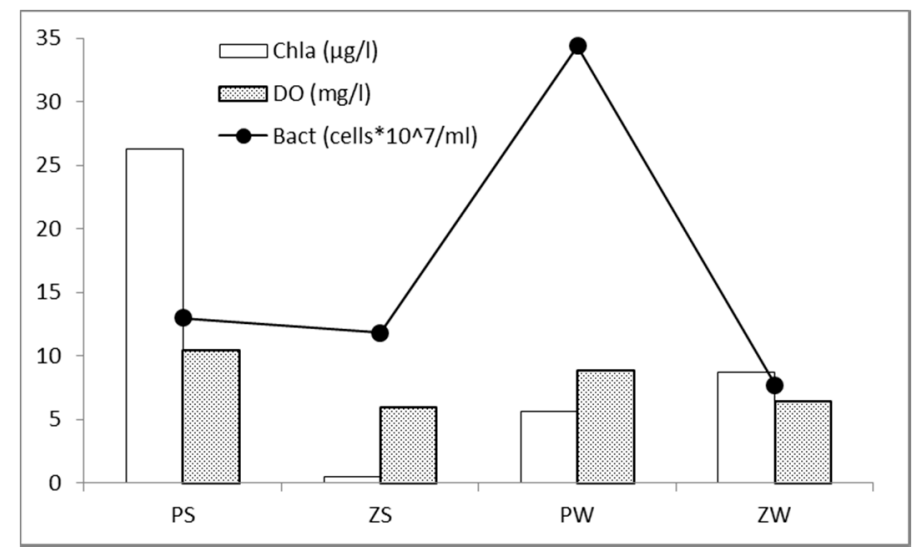

Figure 1. Chlorophyll-a (Chla), dissolved oxygen (DO) and bacterial abundance in Pamvotis (P) and Ziros (Z) Lakes in summer (S) and winter (W).

\subsection{Bacterial Diversity}

A total of 216,702 sequences and 1091 OTUs were obtained after the initial treatment of the data and removal of singletons, chloroplasts and eukaryotic sequences. The number of OTUs (richness) recorded in Pamvotis was 660 in summer, decreasing to 628 OTUs in winter. In Ziros Lake, richness did not vary between summer and winter ( 600 OTUs). Richness and the Chao1 index indicated that the vast majority of OTUs have been revealed during the study (Figure 2). Shannon diversity showed the 
lowest value in Ziros lake (2.88) and the highest in Pamvotis (4.53). Both the minimum and maximum occurred in summer. Evenness (Simpson 1-D) ranged between 0.87 and 0.97 in the different samples.
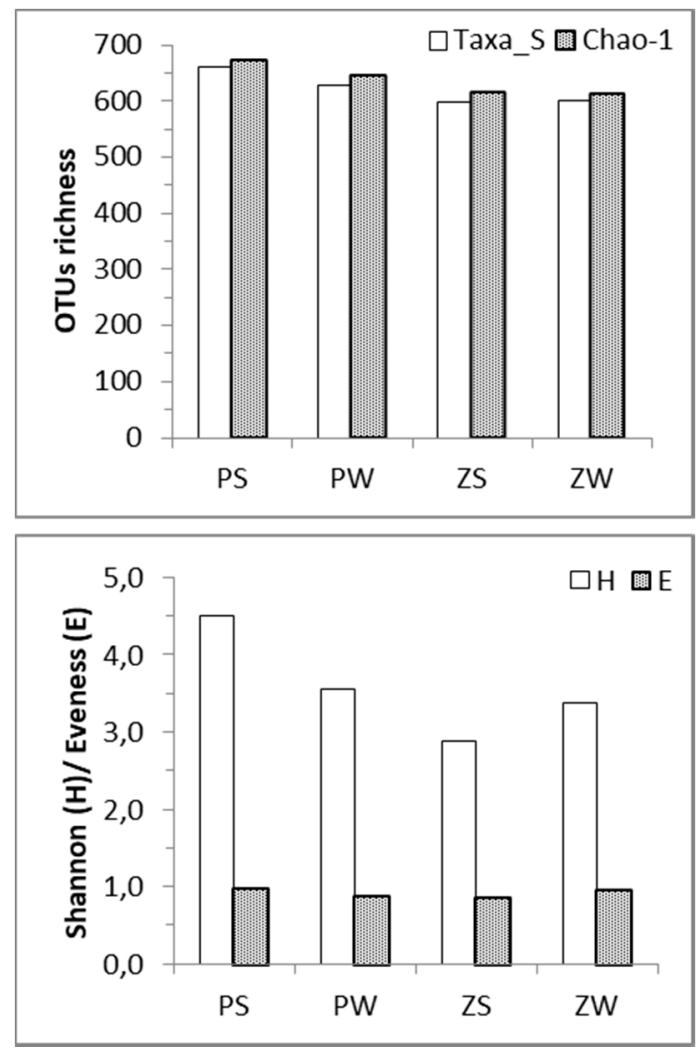

Figure 2. Top: Observed and estimated (Chao1) OTUs richness. Bottom: diversity (Shannon, H) and evenness (Simpson 1-D, E) indices in the two sampling sites $(\mathrm{P}, \mathrm{Z})$ and seasons $(\mathrm{S}, \mathrm{W})$.

The most dominant bacteria phyla were Verrucomicrobia, Proteobacteria, Actinobacteria and Bacteroidetes followed by Cyanobacteria and Planctomycetes (cumulative 75\%, Figure 3). Actinobacteria represented $>30 \%$ in PS, ZS and ZW. In PW the most abundant phylum was Verrucomicrobia ( $>30 \%)$. Proteobacteria relative abundance was $\sim 10 \%$ in Pamvotis but had higher contribution in Ziros lake both in summer $(27.5 \%)$ and in winter $(19.3 \%)$. Bacteroidetes represented $17-21 \%$ in different samples except in ZS where their contribution dropped significantly. At the family level Sporichthyaceae represented $>22 \%$ in PS, ZS, ZW while Rubritaleaceae dominated in ZS (29.7\%, Figure 3). Other abundant families representing more than $10 \%$ in different samples were: Flavobacteriaceae (16\% in PW), Methylophilaceae (14.5\% in ZW), Methylacidiphilacea (13\% in ZS) and SAR11 cladeIII (27.5\% in ZS). At the lowest taxonomic level we found 6 to 47 OTUs representing $75 \%$ of total reads in different samples (Figure 3). OTUs which occurred in high abundances $(>9 \%)$ in our samples included those affiliated to hgcI clade and unidentified Sporichthyaceae, CL500-29 group, Flavobacterium, unidentified Methylophilaceae, SAR11 Clade III and Luteolibacter. Cluster analysis using an unweighted pair-group average (UPGMA) algorithm and based on Morisita similarities between samples at the OTU level indicated similarities $\sim 60 \%$ for ZW and PS. ZS and mainly PW samples were highly differentiated from the other lake communities (Figure 4). The environmental variables were subjected to PCA and components with loadings $>0.5$ were considered in a non-metric multidimensional scaling analysis (NMDS). NMDS (Figure 4) was applied using Bray-Curtis index. Four environmental variables resulted from the PCA analysis (chla, temperature, conductivity, TDS), were fitted a posteriori as arrows in order to estimate their relationship with bacterial community structure [40]. Coordinate 1 was related to temperature and to a lesser extent to chla while Coordinate 2 was related with TDS and conductivity and again, to a lesser extent to chla (Figure 4). 


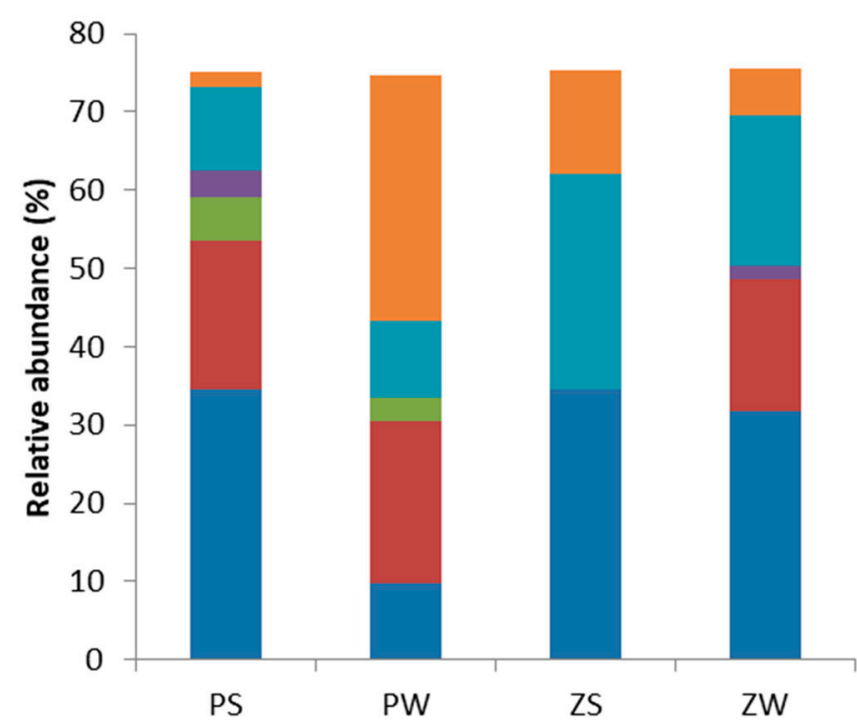

= Verrucromicrobia

n Proteobacteria

n Planctomycetes

n Cyanobacte ria

n Bacteroidetes

actinobacteria

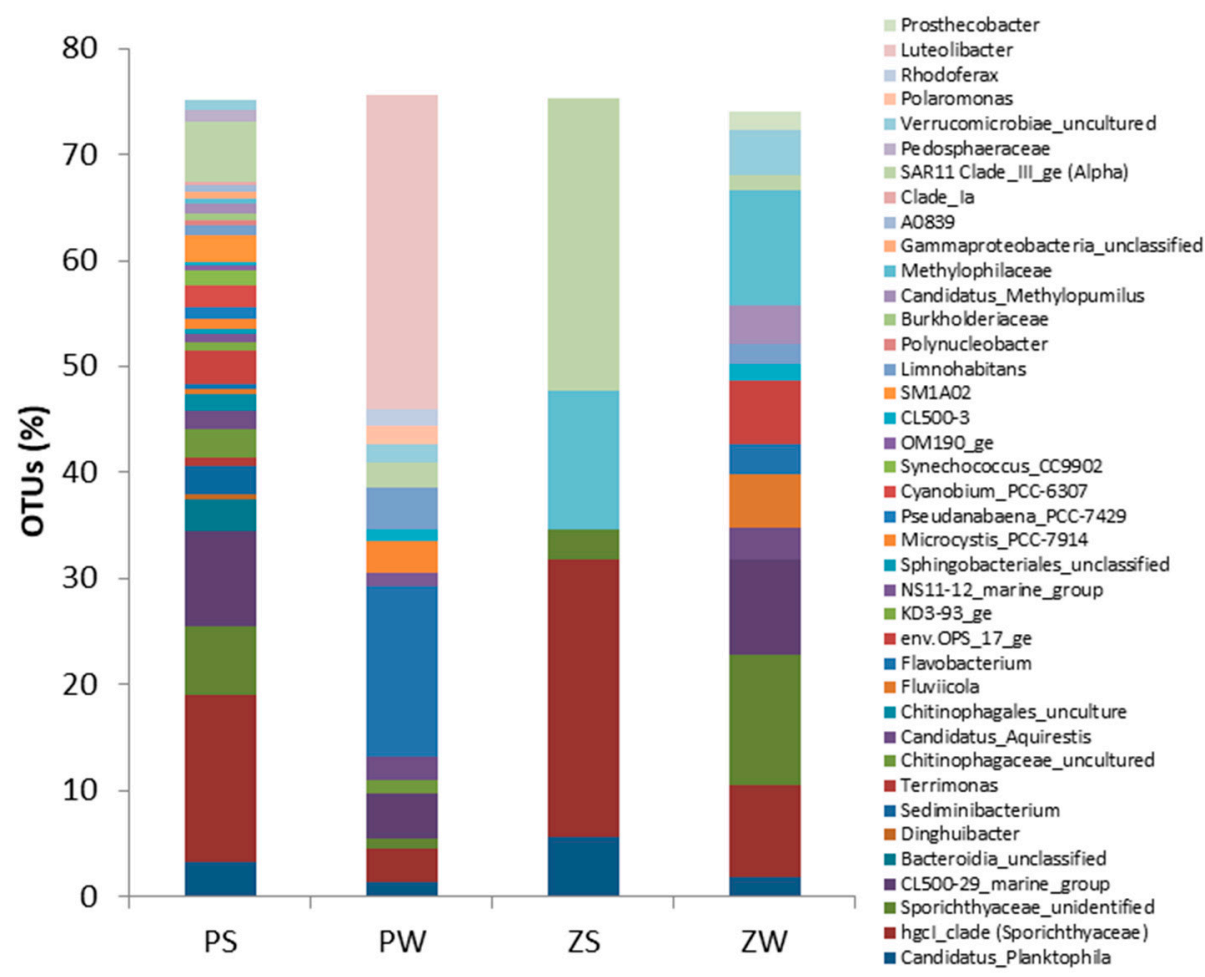

Figure 3. Relative abundance of dominant phyla and OTUs in Pamvotis (P) and Ziros (Z) Lakes in summer (S) and winter (W). 

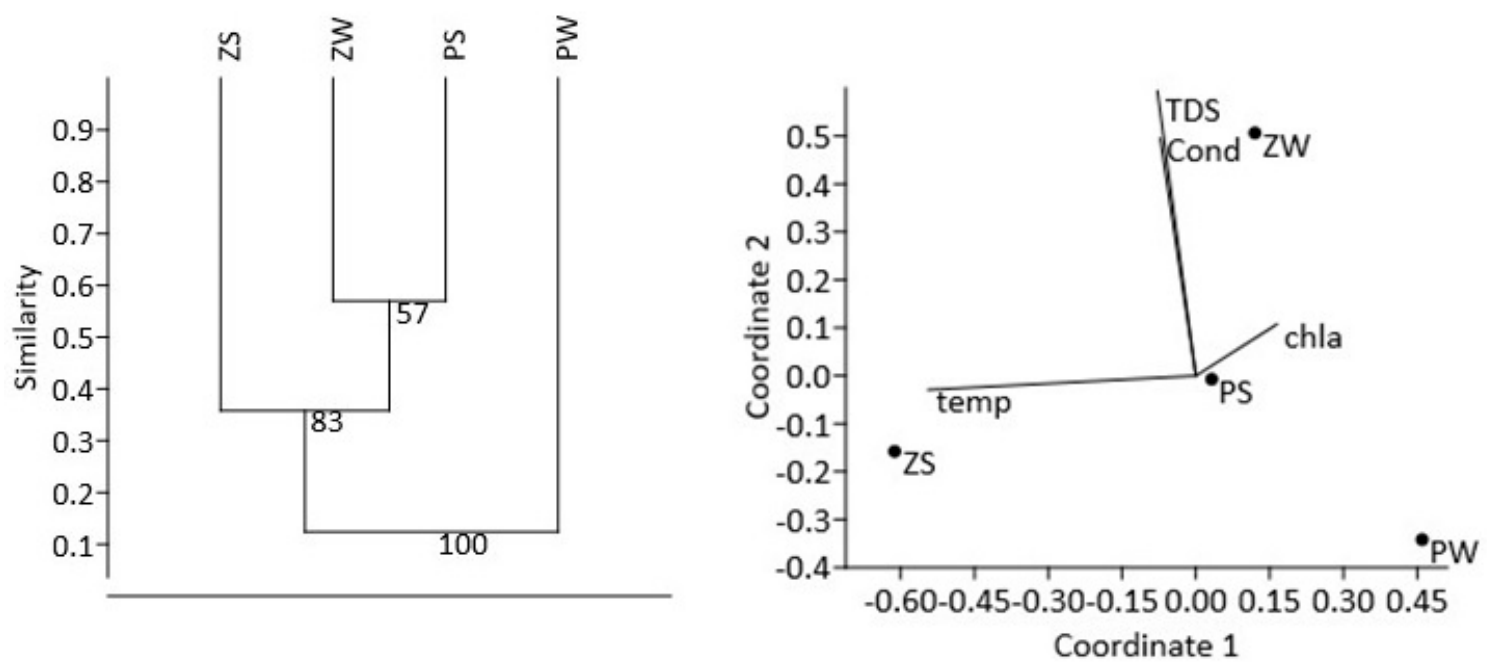

Figure 4. Cluster analysis based on Morisita similarities at the OTU level (left) and NMDS analysis based on Bray-Curtis index with fitted environmental variables (right) for Pamvotis (P) and Ziros (Z) samples in winter (W) and summer (S). Values at the nodes of the cluster correspond to bootstrap values. The correlation coefficients between each environmental variable and the NMDS scores are presented as vectors from the origin. The length of the vectors is arbitrarily scaled and only their directions and relative lengths should be considered. Temp: temperature, TDS: total dissolved solids, cond: conductivity, chla: chlorophyll-a.

\subsection{Microcosm Experiments}

Respiration rates (RR) were estimated during microcosm experiments (slope of linear regression analysis, $p<0.01$, Figure 5). In Pamvotis, $R R$ was $21.11 \mu \mathrm{M} / \mathrm{d}$ in summer, and at the end of the experiment, hypoxic conditions were observed in the experimental bottles $(19.33 \pm 5.40 \mu \mathrm{M}$ or $0.62 \pm 0.17 \mathrm{mg} / \mathrm{L})$. Lower RR were found in PW $(2.87 \mu \mathrm{M} / \mathrm{d})$ as well as in ZS $(2.50 \mu \mathrm{M} / \mathrm{d})$ and $\mathrm{ZW}(2.76 \mu \mathrm{M} / \mathrm{d})$. The slopes of DO concentration over time increased with the rise of temperature by $2{ }^{\circ} \mathrm{C}$ in PS, PW and ZS but decreased in ZW. We did not find any statistically significant differences between regression slopes for the two temperatures tested (in situ and in situ $+2{ }^{\circ} \mathrm{C}$, one-way ANCOVA $p>0.05$ ). However, statistically significant differences were found for RR in PS microcosm when compared to the rest of the treatments (one-way ANCOVA $p<0.001$ ). Respiration rates decreased at the beginning of the experiment and fluctuated thereafter (Figure 4). Respiration rates showed statistically significant correlation (Pearson's $\mathrm{r}$ ) with chla $(\mathrm{r}=0.96, p<0.05)$, T-N $(\mathrm{r}=0.97, p<0.05), \mathrm{NH}_{4}{ }^{+}(\mathrm{r}=0.95$, $p<0.001)$, T-P $(\mathrm{r}=0.97, p<0.05)$ and $\mathrm{PO}_{4}{ }^{3-}(\mathrm{r}=0.97, p<0.05)$. Respiration rates at the beginning of the experiment were statistically correlated with T-P $(\mathrm{r}=0.99, p<0.05)$ and $\mathrm{PO}_{4}{ }^{3-}(\mathrm{r}=0.99, p<0.05)$ as well as with $R R$ measured through the long-term incubation $(r=0.99, p<0.05)$. The effect of temperature was estimated through $Q_{10}$ which was found to increase in Pamvotis from summer (1.33) to winter (2.32). In Ziros lake Q10 peaked in summer (2.78) and decreased to $<1$ in winter. 

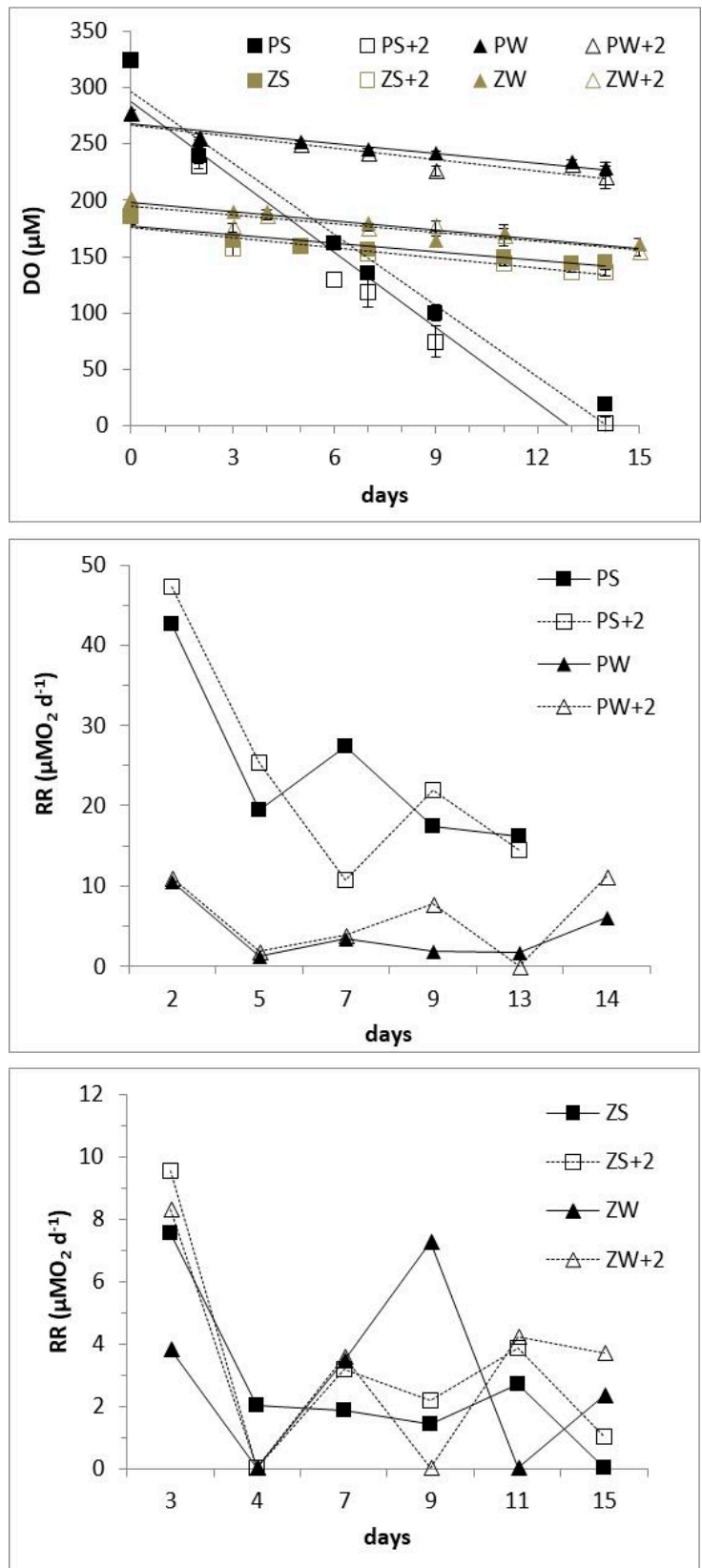

Figure 5. Top: changes in dissolved oxygen (DO) concentration with time. Slopes of regression lines (significance level $p<0.05$ ) represent respiration rates (RR). Middle and bottom: changes in respiration rates (RR) with time. P: Pamvotis, Z: Ziros, S: summer, W: winter. Incubations at in situ temperature and at temperature increased by $2{ }^{\circ} \mathrm{C}(+2)$.

\section{Discussion}

Bacterial diversity was investigated through Illumina sequencing of the hypervariable 3-4 regions of the 16S rRNA, in two lakes of different trophic state in the administrative region of Epirus in Greece. In particular, based on chlorophyll-a values and according to OECD [7] Pamvotis lake was characterized as hypereutrophic $(\sim 26 \mu \mathrm{g} / \mathrm{L})$ in summer. In winter, chla concentration decreased significantly $(\sim 6 \mu \mathrm{g} / \mathrm{L})$. Such low chla values have been previously found in Pamvotis only during the initial years following the start of operations of Ioannina's waste water treatment plant which received a part of the city's sewage [41]. They represent a threshold between mesotrophic and eutrophic conditions and in our study are probably associated with the extreme weather conditions i.e., the very low temperatures and the intense snowfall recorded in the area in previous days (www.meteo.gr). 
In Ziros lake oligotrophic conditions prevailed in summer with chla values $<1 \mu \mathrm{g} / \mathrm{L}$. However, winter measurements support previous studies which characterized the lake as 'mesotrophic with clear signals of eutrophication' [22] since chla was found close to $9 \mu \mathrm{g} / \mathrm{L}$, which represents eutrophic conditions. Classification according to TN compares well with that resulted from chla data except for ZS, which was found to be eutrophic in both sampling periods. TP values showed hypereutrophic conditions [7] in both lakes.

The bacterial communities were dominated by common freshwater phyla like Actinobacteria, Proteobacteria, Bacteroidetes, and Verrucomicrobia [42]. Actinobacteria with relative abundances $>30 \%$ dominated all samples except PW (Pamvotis Winter), and consisted mainly of the cosmopolitan, eutrophic-waters associated, CL500-29 group and hgcl clade [43]. The ecological role of freshwater Actinobacteria was recently revealed through metagenomic analysis [44]. According to this analysis, Actinobacteria perform very well as degraders of recalcitrant organic matter received from the soil and the vascular plants of the watershed, but they are also excellent competitors for nutrients under oligotrophic conditions [44]. So, their predominance in the two lakes with rural and agricultural watersheds (along with urban and industrial activities in the case of Pamvotis) should probably be expected. On the other hand, Pamvotis is a lake with frequent and intense cyanobacterial blooms [45] and the low relative abundance of Cyanobacteria in our samples was surprising. A previous study [44] showed a negative correlation between Actinobacteria and Cyanobacteria, the former not being able to outcompete the latter under conditions that promote cyanobacterial blooms (i.e., high nutrient availability and temperature) and suggested that the predominance of Actinobacteria could be regarded as a sign of 'impending ecological catastrophes'. A fine scale temporal study, during the warm period of the year that promotes the bloom in Pamvotis, would be needed to investigate if succession patterns exist for different autotrophic and heterotrophic bacterial taxa i.e., if Cyanobacteria replace Actinobacteria during the warm period of the year. However, we should also consider some methodological constraints. For example, the choice of $16 S$ rRNA region may affect apparent community structure, although Actinobacteria and Cyanobacteria abundance profiles do not seem to differentiate for primers targeting different hypervariable regions [46]. Finally, it seems that the simultaneous use of molecular and microscopy/morphological techniques would help elucidate these controversies $[47,48]$.

In Pamvotis lake in winter, Actinobacteria dropped to $<10 \%$ and instead, Verrucomicrobia occurred in relative abundance $>30 \%$. These data support recent findings that Verrucomicrobia may constitute a high fraction of the bacterial communities [49]. The phylum has been associated with phytoplankton blooms and/or specific complex substrates [50,51] and single cell genomics have revealed genes for enzymes degrading a wide spectrum of polysaccharides by its representatives [52]. The vast majority of Verrucomicrobia $(>29 \%$ ) constituted of an OTU associated with the phycrophilic/psychrotolerant genus Luteolibacter [53]. Thus low temperatures $\left(3.8^{\circ} \mathrm{C}\right)$, probably in combination with the presence of specific substances in the water column [51], triggered the growth and dominance of this particular taxon in Pamvotis lake in winter. Compared to Actinobacteria and Verrucomicrobia, Bacteroidetes' ecological role in freshwater ecosystems is well known. They degrade autochthonous and allochthonous dissolved organic carbon and so they usually occur in high abundance under post-bloom conditions [54]. In this study, similarly to Schiaffino et al. [55], a higher contribution of Bacteroidetes to community structure was found under mesotrophic to hypereutrophic conditions than under oligotrophic conditions.

An indication of methylotrophic activity in Lake Ziros has been revealed through the detection of OTUs affiliated to Methilophilaceae (Gammaproteobacteria) considered as obligate or restricted facultative methylotrophs [56], in high relative abundance $(<10 \%)$, both during the low and the high chla periods. In winter, $\sim 4 \%$ of the sequences were affiliated to Candidatus Methylopumilus. Our data are few but they do not show a clear trend of methylotrophs abundance with chla, nutrient concentration or temperature as it has been suggested previously [57]. Ziros lake is surrounded by a dense forest of Fraxinus angustifolia oxycarpa and several other tree species. It is likely that methylotrophs are favored by the growth and decay of these plant species, which are sources of single-carbon (C1) substrates used for their metabolism [58]. 
Cluster analysis based on Morisita index showed a grouping (similarity $>50 \%$ ) of bacterial communities from eutrophic and hypereutrophic waters i.e., of those retrieved from Ziros in winter and Pamvotis in summer. Ziros summer (ZS, oligotrophic) and Pamvotis winter (PW, mesotrophic) samples occupied separate branches of the cluster with PW being the most dissimilar. These results differ from previous studies, which showed mesotrophic waters to exhibit similarities either to oligotrophic or to eutrophic waters $[17,18]$. The complete differentiation of the bacterial community in mesotrophic PW from the other samples supports the suggestion that extreme water physicochemical conditions, like the low temperatures recorded in this study, can shape communities and select taxa that cope well with harsh environment [59]. Actually, NMDS analysis indicated temperature as a factor affecting the community structure of PW. Thus a psychrophilic/psychrotolerant community developed in winter with high dissimilarities to those recorded in the other samplings. Shannon index of bacterial diversity increased with chla, in response to the higher spatial heterogeneity of the more productive waters [21]. This could also explain the relatively high similarity of bacterial communities in the two 'high' chla samples. It was interesting however that these communities did not show similarities in terms of their metabolic performance (respiratory rates) during the long-term microcosm experiment. Actually, in PS microcosms, the rate of decrease of DO $(>20 \mathrm{mg} / \mathrm{L} / \mathrm{d})$ was higher compared to the rest of the microcosms $(<0.2 \mathrm{mg} / \mathrm{L} / \mathrm{d})$ resulting in hypoxic conditions $(<2 \mathrm{mg} / \mathrm{L})$ at the end of the incubation period. On the other hand the highly differentiated communities of PW, ZW and ZS had similar respiration rates. Our results should be interpreted with caution and may not be extrapolated to natural conditions due to long-term incubations and associated bottle effects e.g., use of refractory carbon, growth of opportunistic species, accumulation of toxic byproducts, [60-62]. Furthermore, autotrophic respiration may have contributed to total respiration at least at the beginning of the experiment. However, based on the initial assumptions there is strong evidence that oxygen consumption in the bottles is mainly due to bacterial activity. Previous studies using long-term incubations estimated that heterotrophic bacteria contribute $~ 50 \%$ to community [36] and $87 \%$ to pico-planktonic size fraction [63] respiration. In this framework, the above findings have implications for ecosystems functioning since shifts in bacterial communities composition allow their assemblages to adapt to habitat 'peculiarities' not investigated here (e.g., substrate availability and quality), so that the outcome in terms of oxygen consumption is the same for the different assemblages i.e., they show similar respiration rates over a range of chla concentrations and temperatures found in the two lakes. For example, in Ziros lake in winter, 20 OTUs constituted $75 \%$ of total reads and were affiliated mainly to Actinobacteria $(\sim 32 \%)$, Bacteroidetes ( $17 \%)$ and Gammaproteobacteria ( $18 \%$, Methylophilaceae but also Limnohabitans). In summer, fewer OTUs (6) constituted $75 \%$ of reads and besides Actinobacteria which had similar relative abundance as in winter, we found OTUs affiliated to the clade SAR11-III (Alphaproteobacteria) to thrive ( $28 \%)$. SAR11-III has two lineages, the oligo/mesohaline SAR-IIIa and the freshwater SAR11-IIIb [64]. Since conductivity in Ziros was extremely low, we can speculate that the detected OTU in ZS was associated to the SAR11-IIIb ultramicrobacterium with the oligotrophic lifestyle [65]. As mentioned above, we expect bacterial community structure in the experimental bottles to change during the experiment and we believe that low temporal fluctuations of respiratory rates in the microcosms reflect these changes. The succession pattern is associated not only with the environmental conditions that prevail in the bottles [e.g., available organic substrates, 61] but also to the initial bacterial assemblage [66]. Qualitative changes in bacterial community composition have also been shown previously in freshwater plankton respiration experiments [67] and this is probably a reason for the lack of correlation between respiration and bacterial abundance, size or growth [4].

Respiration rates did not change significantly for a temperature rise of $2{ }^{\circ} \mathrm{C}$; however, $\mathrm{Q}_{10}$ index allowed for the investigation of possible temperature effects under the different conditions met in the two lakes. Our results indicated a high temperature effect at the cold temperatures recorded in Pamvotis in winter $\left(3.8^{\circ} \mathrm{C}\right)$ as has also been previously shown for marine waters [68]. On the contrary in Ziros lake the temperature effect was more pronounced in summer when high temperatures occurred $\left(27.9^{\circ} \mathrm{C}\right)$. It has been suggested that at high temperatures respiration is regulated by the availability of 
substrates and/or demands for energy flow $[5,69]$. Thus, we could suggest that the high $\mathrm{Q}_{10}$ values are due to resource limitations associated with the oligotrophic conditions that prevailed.

The rates, at which ecosystem's nutrients recycle, are determined primarily by the actions of their constituent organisms [70]. While at a high taxonomic level we found similarities between samples, constituent OTUs differed reflecting heterogeneities in their habitats. It has been previously suggested that differently composed bacterial communities maintain similar large scale functions like respiration [71]. Our results, although based on few observations from two lakes characterized by distinct oligotrophic to eutrophic/hypereutrophic conditions, corroborate this hypothesis. Furthermore it seems that this functional redundancy might mitigate the impacts of warming in aquatic ecosystems. However, oxygen consumption increased under highly eutrophic conditions. These elevated levels of functioning (respiration) did not reflect a rise of bacterial abundance but are probably related to high competition between taxa when bacterial diversity increased [72]. These results indicate that distinct bacterial communities occur under different lake trophic states as revealed by chlorophyll-a and based on OECD classification. Further studies on a large network of freshwater lakes are needed to confirm such a pattern and to investigate whether water bodies of different trophic state have specific bacterial signatures. Thus, monitoring bacterial communities could become a useful tool for the assessment of the ecological quality of freshwater lakes.

Author Contributions: Conceptualization, H.K.; Data curation, H.K. and S.C.M.; Formal analysis, H.K., S.C.M., V.T. and D.A.; Investigation, H.K. and V.T.; Methodology, H.K., S.C.M., V.T. and D.A.; Writing一original draft, H.K.; Writing-review \& editing, H.K., S.C.M., V.T. and D.A.

Funding: This research received no external funding.

Acknowledgments: The authors acknowledge use of the services and facilities of Computer Center of NTUA-Greece and specially C. Fragkoudakis and M. Karabatsis for their assistance, as well as E. Evans for proof-reading.

Conflicts of Interest: The authors declare no conflict of interest.

\section{References}

1. Azam, F.; Fenchel, T.; Field, J.G.; Graf, J.S.; Meyer-Rei, L.-A.; Thingstad, F. The Ecological Role of Water-Column Microbes in the Sea. Mar. Ecol. Prog. Ser. 1983, 10, 257-263. [CrossRef]

2. Sakamoto, C.; Yamaguchi, N.; Nasu, M. Rapid and simple quantification of bacterial cells by using a microfluidic device. Appl. Environ. Microbiol. 2005, 71, 1117-1121. [CrossRef] [PubMed]

3. Comte, J.; Fauteux, L.; del Giorgio, P.A. Links between metabolic plasticity and functional redundancy in freshwater bacterioplankton communities. Front. Microbiol. 2013, 4, 112. [CrossRef] [PubMed]

4. Pomeroy, L.R.; Sheldon, J.E.; Sheldon, W.M. Changes in Bacterial Numbers and Leucine Assimilation during Estimations of Microbial Respiratory Rates in Seawater by the Precision Winkler Method. Appl. Environ. Microbiol. 1994, 60, 328-332. [PubMed]

5. Smith, E.M.; Prairie, Y.T. Bacterial metabolism and growth efficiency in lakes: The importance of phosphorus availability. Limnol. Oceanogr. 2004, 49, 137-147. [CrossRef]

6. French, T.D.; Petticrew, E.L. Chlorophyll a seasonality in four shallow eutrophic lakes (northern British Columbia, Canada) and the critical roles of internal phosphorus loading and temperature. Hydrobiologia 2007, 575, 285-299. [CrossRef]

7. OECD. Eutrophication of Waters. Monitoring, Assessment and Control; Organisation for Economic Co-Operation and Development: Paris, France, 1982; p. 154.

8. Tsola, S.L.; Renta, C.; Macingo, S.C.; Karayanni, H. Investigating size-fractionated chlorophyll a and phycocyanin temporal variations in a highly eutrophic lake and its isolated karstic springs. Oceanol. Hydrobiol. Stud. 2018, 47, 118-127. [CrossRef]

9. Bird, D.F.; Kalff, J. Empirical relationship between bacterial abundance and chlorophyll concentration in fresh and marine waters. Can. J. Fish. Aquat. Sci. 1984, 41, 1015-1023. [CrossRef]

10. Inyang, A.A.E.; Dan, M. Bacterial Abundance-Chlorophyll a Concentration Relationships in Cross River Basin, Southeastern Nigeria: An Evaluation of Empirical Bacterial Abundance-Chlorophyll a Models Using a Multivariate Analysis. J. Water Resour. Ocean Sci. 2015, 4, 72-85. 
11. Muylaert, K.; Van Der Gucht, K.; Vloemans, N.; Meester, L.D.; Gillis, M.; Vyverman, W. Relationship between bacterial community composition and bottom-up versus top-down variables in four eutrophic shallow lakes. Appl. Environ. Microbiol. 2002, 68, 4740-4750. [CrossRef] [PubMed]

12. Akins, L.; Ayayee, P.; Leff, L.G. Composition and diversity of cyanobacteria-associated and free-living bacterial communities during cyanobacterial blooms. Ann. Microbiol. 2018, 68, 493-503. [CrossRef]

13. Louati, I.; Pascault, N.; Debroas, D.; Bernard, C.; Humbert, J.F.; Leloup, J. Structural Diversity of Bacterial Communities Associated with Bloom-Forming Freshwater Cyanobacteria Differs According to the Cyanobacterial Genus. PLoS ONE 2015, 10, e0140614. [CrossRef] [PubMed]

14. Niu, Y.; Shen, H.; Chen, J.; Xie, P.; Yang, X.; Tao, M.; Ma, Z.; Qi, M. Phytoplankton community succession shaping bacterioplankton community composition in Lake Taihu, China. Water Res. 2011, 45, 4169-4182. [CrossRef] [PubMed]

15. Ylla, I.; Peter, H.; Romani, A.M.; Tranvik, L.J. Different diversity-functioning relationship in lake and stream bacterial communities. FEMS Microbiol. Ecol. 2013, 85, 95-103. [CrossRef] [PubMed]

16. Keshri, J.; Pradeep Ram, A.S.; Nana, P.A.; Sime-Ngando, T. Taxonomical Resolution and Distribution of Bacterioplankton along the Vertical Gradient Reveals Pronounced Spatiotemporal Patterns in Contrasted Temperate Freshwater Lakes. Microb. Ecol. 2018, 76, 372-386. [CrossRef] [PubMed]

17. De Figueiredo, D.R.; Pereira, M.J.; Moura, A.; Silva, L.; Barrios, S.; Fonseca, F.; Henriques, I.; Correia, A. Bacterial community composition over a dry winter in meso- and eutrophic Portuguese water bodies. FEMS Microbiol. Ecol. 2007, 59, 638-650. [CrossRef] [PubMed]

18. Llíros, M.; Inceoglu, O.; Garcia-Armisen, T.; Anzil, A.; Leporcq, B.; Pigneur, L.M.; Viroux, L.; Darchambeau, F.; Descy, J.P.; Servais, P. Bacterial community composition in three freshwater reservoirs of different alkalinity and trophic status. PLoS ONE 2014, 9, e116145. [CrossRef] [PubMed]

19. Newton, R.J.; McLellan, S.L. A unique assemblage of cosmopolitan freshwater bacteria and higher community diversity differentiate an urbanized estuary from oligotrophic Lake Michigan. Front. Microbiol. 2015, 6, 1028. [CrossRef] [PubMed]

20. Mohiuddin, M.M.; Botts, S.R.; Paschos, A.; Schellhorn, H.E. Temporal and spatial changes in bacterial diversity in mixed use watersheds of the Great Lakes region. J. Great Lakes Res. 2019, 45, 109-118. [CrossRef]

21. Jankowski, K.; Schindler, D.E.; Horner-Devine, M.C. Resource availability and spatial heterogeneity control bacterial community response to nutrient enrichment in lakes. PLoS ONE 2014, 9, e86991. [CrossRef] [PubMed]

22. Kagalou, I.; Psilovikos, A. Assessment of the typology and the trophic status of two Mediterranean lake ecosystems in Northwestern Greece. Water Resour. 2014, 41, 335-343. [CrossRef]

23. Papastergiadou, E.; Kagalou, I.; Stefanidis, K.; Retalis, A.; Leonardos, I. Effects of Anthropogenic Influences on the Trophic State, Land Uses and Aquatic Vegetation in a Shallow Mediterranean Lake: Implications for Restoration. Water Resour. Manag. 2010, 24, 415-435. [CrossRef]

24. Kormas, K.A.; Vardaka, E.; Moustaka-Gouni, M.; Kontoyanni, V.; Petridou, E.; Gkelis, S.; Neofitou, C. Molecular detection of potentially toxic Cyanobacteria and their associated Bacteria in lake water column and sediment. World J. Microbiol. Biotechnol. 2010, 26, 1473-1482. [CrossRef]

25. Meziti, A.; Tsementzi, D.; Ar Kormas, K.; Karayanni, H.; Konstantinidis, K.T. Anthropogenic effects on bacterial diversity and function along a river-to-estuary gradient in Northwest Greece revealed by metagenomics. Environ. Microbiol. 2016, 18, 4640-4652. [CrossRef] [PubMed]

26. Meziti, A.; Tsementzi, D.; Rodriguez, R.L.; Hatt, J.K.; Karayanni, H.; Kormas, K.A.; Konstantinidis, K.T. Quantifying the changes in genetic diversity within sequence-discrete bacterial populations across a spatial and temporal riverine gradient. ISME J. 2019, 13, 767-779. [CrossRef] [PubMed]

27. Baltar, F.; Lindh, M.V.; Parparov, A.; Berman, T.; Pinhassi, J. Prokaryotic community structure and respiration during long-term incubations. Microbiologyopen 2012, 1, 214-224. [CrossRef] [PubMed]

28. Hobbie, J.E.; Peterson, P.J.; Bettez, N.; Deegan, L.; O’Brien, W.J.; Kling, G.W.; Kipphut, G.W.; Bowden, W.B.; Hershey, A.E. Impact of global change on the biogeochemistry and ecology of an Arctic freshwater system. Polar Res. 1999, 18, 207-214. [CrossRef]

29. Porter, K.G.; Feig, Y.S. The use of DAPI for identifying and counting aquatic microflora. Limnol. Oceanogr. 1980, 25, 943-948. [CrossRef] 
30. Klindworth, A.; Pruesse, E.; Schweer, T.; Peplies, J.; Quast, C.; Horn, M.; Glockner, F.O. Evaluation of general $16 S$ ribosomal RNA gene PCR primers for classical and next-generation sequencing-based diversity studies. Nucleic Acids Res. 2013, 41, e1. [CrossRef] [PubMed]

31. Schloss, P.D.; Westcott, S.L.; Ryabin, T.; Hall, J.R.; Hartmann, M.; Hollister, E.B.; Lesniewski, R.A.; Oakley, B.B.; Parks, D.H.; Robinson, C.J.; et al. Introducing mothur: Open-source, platform-independent, community-supported software for describing and comparing microbial communities. Appl. Environ. Microbiol. 2009, 75, 7537-7541. [CrossRef] [PubMed]

32. Pruesse, E.Q.C.; Knittel, K.; Fuchs, B.; Ludwig, W.; Peplies, J.; Glöckner, F. Silva: A comprehensive online resource for quality checked and aligned ribosomal RNA sequence data compatible with ARB. Nucleic Acids Res. 2007, 35, 7188-7196. [CrossRef] [PubMed]

33. Labasque, T.C.C.; Aminot, A.; Kergoat, G. Spectrophotometric Winkler determination of dissolved oxygen: Reexamination of critical factors and reliability. Mar. Chem. 2004, 88, 53-60. [CrossRef]

34. Apple, J.K.; del Giorgio, P.A.; Kemp, W.M. Temperature regulation of bacterial production, respiration, and growth efficiency in a temperate salt-marsh estuary. Aquat. Microb. Ecol. 2006, 43, 243-254. [CrossRef]

35. Felip, M.; Pace, M.L.; Cole, J.J. Regulation of planktonic bacterial growth rates: The effects of temperature and resources. Microb. Ecol. 1996, 31, 15-28. [CrossRef] [PubMed]

36. Berman, T.; Yacobi, Y.Z.; Parparov, A.; Gal, G. Estimation of long-term bacterial respiration and growth efficiency in Lake Kinneret. FEMS Microbiol. Ecol. 2010, 71, 351-363. [CrossRef] [PubMed]

37. Pace, M.L.; Prairie, Y.T. Respiration in Lakes; Oxford University Press: Oxford, UK, 2005.

38. García-Martín, E.-E.; Serret, P.; Érez-Lorenzo, M. Testing potential bias in marine plankton respiration rates by dark bottle incubations in the NW Iberian shelf: Incubation time and bottle volume. Cont. Shelf Res. 2010, 31, 496-506. [CrossRef]

39. Pratt, D.M.; Berkson, H. Two sources of error in the oxygen light and dark bottle method. Limnol. Oceanogr. 1954, 4, 328-334. [CrossRef]

40. Ramette, A. Multivariate analyses in microbial ecology. FEMS Microbiol. Ecol. 2007, 62, 142-160. [CrossRef] [PubMed]

41. Kagalou, I.; Papastergiadou, E.; Leonardos, I. Long term changes in the eutrophication process in a shallow Mediterranean lake ecosystem of W. Greece: Response after the reduction of external load. J. Environ. Manag. 2008, 87, 497-506. [CrossRef] [PubMed]

42. Newton, R.J.; Shade, A. Lifestyles of rarity: Understanding heterotrophic strategies to inform the ecology of the microbial rare biosphere. Aquat. Microb. Ecol. 2016, 78, 51-63. [CrossRef]

43. Yang, C.; Wang, Q.; Simon, P.N.; Liu, J.; Liu, L.; Dai, X.; Zhang, X.; Kuang, J.; Igarashi, Y.; Pan, X.; et al. Distinct Network Interactions in Particle-Associated and Free-Living Bacterial Communities during a Microcystis aeruginosa Bloom in a Plateau Lake. Front. Microbiol. 2017, 8, 1202. [CrossRef] [PubMed]

44. Ghai, R.; Mizuno, C.M.; Picazo, A.; Camacho, A.; Rodriguez-Valera, F. Key roles for freshwater Actinobacteria revealed by deep metagenomic sequencing. Mol. Ecol. 2014, 23, 6073-6090. [CrossRef] [PubMed]

45. Vardaka, E.; Moustaka-Gouni, M.; Cook, C.M.; Lanaras, T. Cyanobacterial blooms and water quality in Greek waterbodies. J. Appl. Phycol. 2005, 17, 391-401. [CrossRef]

46. Parulekar, N.N.; Kolekar, P.; Jenkins, A.; Kleiven, S.; Utkilen, H.; Johansen, A.; Sawant, S.; Kulkarni-Kale, U.; Kale, M.; Saebo, M. Characterization of bacterial community associated with phytoplankton bloom in a eutrophic lake in South Norway using $16 S$ rRNA gene amplicon sequence analysis. PLoS ONE 2017, 12, e0173408. [CrossRef] [PubMed]

47. McManus, G.B.; Kantz, L.A. Molecular and morphological methods for identifying plankton: What makes a successful marriage? J. Plankton Res. 2009, 31, 1119-1129. [CrossRef]

48. Oikonomou, A.; Katsiapi, M.; Karayanni, H.; Moustaka-Gouni, M.; Kormas, K.A. Plankton microorganisms coinciding with two consecutive mass fish kills in a newly reconstructed lake. Sci. World J. 2012, 2012, 504135. [CrossRef] [PubMed]

49. Chiang, E.; Schmidt, M.L.; Berry, M.A.; Biddanda, B.A.; Burtner, A.; Johengen, T.H.; Palladino, D.; Denef, V.J. Verrucomicrobia are prevalent in north-temperate freshwater lakes and display class-level preferences between lake habitats. PLOS ONE 2018, 13, e0195112.

50. Cai, H.; Jiang, H.; Krumholz, L.R.; Yang, Z. Bacterial community composition of size-fractioned aggregates within the phycosphere of cyanobacterial blooms in a eutrophic freshwater lake. PLoS ONE 2014, 9, e102879. [CrossRef] [PubMed] 
51. Cardman, Z.; Arnosti, C.; Durbin, A.; Ziervogel, K.; Cox, C.; Steen, A.D.; Teske, A. Verrucomicrobia are candidates for polysaccharide-degrading bacterioplankton in an arctic fjord of Svalbard. Appl. Environ. Microbiol. 2014, 80, 3749-3756. [CrossRef] [PubMed]

52. Martinez-Garcia, M.; Brazel, D.M.; Swan, B.K.; Arnosti, C.; Chain, P.S.; Reitenga, K.G.; Xie, G.; Poulton, N.J.; Lluesma Gomez, M.; Masland, D.E.; et al. Capturing single cell genomes of active polysaccharide degraders: An unexpected contribution of Verrucomicrobia. PLoS ONE 2012, 7, e35314. [CrossRef] [PubMed]

53. Fang, L.; Chen, L.; Liu, Y.; Tao, W.; Zhang, Z.; Liu, H.; Tang, Y. Planktonic and sedimentary bacterial diversity of Lake Sayram in summer. MicrobiologyOpen 2015, 4, 814-825. [CrossRef] [PubMed]

54. Newton, R.J.; Jones, S.E.; Eiler, A.; McMahon, K.D.; Bertilsson, S. A Guide to the Natural History of Freshwater Lake Bacteria. Microbiol. Mol. Boil. Rev. 2011, 75, 14-49. [CrossRef] [PubMed]

55. Schiaffino, M.R.; Sánchez, M.L.; Gerea, M.; Unrein, F.; Balagué, V.; Gasol, J.M.; Izaguirre, I. Distribution patterns of the abundance of major bacterial and archaeal groups in Patagonian lakes. J. Plankton Res. 2016, 38, 64-82. [CrossRef]

56. Doronina, N.; Kaparullina, E.; Trotsenko, Y. The Family Methylophilaceae. In The Prokaryotes; Rosenberg, E., DeLong, E.F., Lory, S., Stackebrandt, E., Thompson, F., Eds.; Springer: Berlin/Heidelberg, Germany, 2014; pp. 869-880.

57. Salcher, M.M.; Neuenschwander, S.M.; Posch, T.; Pernthaler, J. The ecology of pelagic freshwater methylotrophs assessed by a high-resolution monitoring and isolation campaign. ISME J. 2015, 9, 2442-2453. [CrossRef] [PubMed]

58. Chistoserdova, L. Methylotrophy in a Lake: From Metagenomics to Single-Organism Physiology. Appl. Environ. Microb. 2011, 77, 4705-4711. [CrossRef] [PubMed]

59. Han, M.; Gong, Y.; Zhou, C.; Zhang, J.; Wang, Z.; Ning, K. Comparison and Interpretation of Taxonomical Structure of Bacterial Communities in Two Types of Lakes on Yun-Gui plateau of China. Sci. Rep. 2016, 6, 30616. [CrossRef] [PubMed]

60. Carlson, C.A.; Bates, N.R.; Ducklow, H.W.; Hansell, D.A. Estimation of bacterial respiration and growth efficiency in the Ross Sea, Antarctica. Aquat. Microb. Ecol. 1999, 19, 229-234. [CrossRef]

61. Del Giorgio, P.A.; Cole, J.J. Bacterial growth efficiency in natural aquatic ecosystems. Annu. Rev. Ecol. Syst. 1998, 29, 503-541. [CrossRef]

62. Massana, R.; Pedrós-Alio, C.; Casamayor, E.O.; Gasol, J.M. Changes in marine bacterioplankton phylogenetic composition during incubations designed to measure biogeochemically significant parameters. Limnol. Oceanogr. 2001, 46, 1181-1188. [CrossRef]

63. Cuevas, L.A.; Egge, J.K.; Thingstad, T.F.; Töpper, B. Organic carbon and mineral nutrient limitation of oxygen consumption, bacterial growth and efficiency in the Norwegian Sea. Polar Biol. 2011, 34, 871-882. [CrossRef]

64. Herlemann, D.P.; Woelk, J.; Labrenz, M.; Jurgens, K. Diversity and abundance of "Pelagibacterales" (SAR11) in the Baltic Sea salinity gradient. Syst. Appl. Microbiol. 2014, 37, 601-604. [CrossRef] [PubMed]

65. Salcher, M.M.; Pernthaler, J.; Posch, T. Seasonal bloom dynamics and ecophysiology of the freshwater sister clade of SAR11 bacteria 'that rule the waves' (LD12). ISME J. 2011, 5, 1242-1252. [CrossRef] [PubMed]

66. Karayanni, H.; Meziti, A.; Spatharis, S.; Genitsaris, S.; Courties, C.; Kormas, K.A. Changes in Microbial (Bacteria and Archaea) Plankton Community Structure after Artificial Dispersal in Grazer-Free Microcosms. Microorganisms 2017, 5, 31. [CrossRef] [PubMed]

67. Gattuso, J.P.; Peduzzi, S.; Pizay, M.D.; Tonolla, M. Changes in freshwater bacterial community composition during measurements of microbial and community respiration. J. Plankton Res. 2002, 24, 1197-1206. [CrossRef]

68. Pomeroy, L.; Wiebe, W.; Deibel, D.; Thompson, R.; Rowe, G.; Pakulski, J. Bacterial responses to temperature and substrate concentration during the Newfoundland spring bloom. Mar. Ecol. Prog. Ser. 1991, 75, 146-159. [CrossRef]

69. Atkin, O.K.; Bruhn, D.; Tjoelker, M.G. Response of Plant Respiration to Changes in Temperature: Mechanisms and Consequences of Variations in Q10 Values and Acclimation; Springer: Dordrecht, The Netherlands, 2005; Volume 18.

70. Armitage, D.W. Time-variant species pools shape competitive dynamics and biodiversity-ecosystem function relationships. Proc. R. Soc. B Boil. Sci. 2016, 283, 20161437. [CrossRef] [PubMed] 
71. Langenheder, S.; Lindstrom, E.S.; Tranvik, L.J. Weak coupling between community composition and functioning of aquatic bacteria. Limnol. Oceanogr. 2005, 50, 957-967. [CrossRef]

72. Becker, S.; Richl, P.; Ernst, A. Seasonal and habitat-related distribution pattern of Synechococcus genotypes in Lake Constance. FEMS Microbiol. Ecol. 2007, 62, 64-77. [CrossRef] [PubMed]

(․) (1) (C) 2019 by the authors. Licensee MDPI, Basel, Switzerland. This article is an open access article distributed under the terms and conditions of the Creative Commons Attribution (CC BY) license (http:/ / creativecommons.org/licenses/by/4.0/). 